\title{
SOME PHRASEOLOGICAL UNITS IN THE PROCESS OF TRANSLATION AND ADAPTION
}

\author{
ALGUMAS UNIDADES FRASEOLÓGICAS NO PROCESSO DE TRADUÇÃO E \\ ADAPTAÇÃO
}

\author{
ALGUNAS UNIDADES FRASEOLÓGICAS EN PROCESO DE TRADUCCIÓN Y \\ ADAPTACIÓN
}

\author{
Elvira Rafilovna YILMAZ ${ }^{1}$ \\ Elmira Kamilevna KHABIBULLINA ${ }^{2}$ \\ Alfiya Rafisovna ALIKBEROVA ${ }^{3}$
}

\begin{abstract}
The article deals with the problem of working with some forms of phraseological units in translated and adapted texts of the news genre. To get a clearer idea of the role of idioms and collocations in the context of the news genre, we turned to the materials published in the period from January to May 2020 in English, Russian and Turkish on the leading news sites. At the same time, we selected and analyzed both translated articles and texts that are information adaptations of the desired message. Also, attention was paid to the issue of phraseology of collocations. Since there are still disputes regarding the distinction between translation (as a result of the translator's actions) and adapted text, it was necessary to raise the question of the definition of adapted and translated texts. To create a complete picture, the research also included the definition of other terms and concepts used to refer to a linguistic phenomenon in one of the three languages of the above texts. In the adapted information texts, there are numerous examples of using phraseological units, which in some cases coincide in similar messages in different languages. When working with examples, we followed the following tactics. To select examples of adapted text, we looked at news articles that contain the same information, have a link to the same source of information, and were published within a period of no more than 24 hours. We also took the texts of eponymous publications published in different languages and aimed at different potential audiences but carrying the same information and published with a difference of no more than a day. The most common adaptation of collocation is due to the greatest flexibility of these types of phraseological units.
\end{abstract}

KEYWORDS: Informational text. Turkish language. English language. Collocation. Adaptation.

RESUMO: O artigo trata do problema de trabalhar algumas formas de unidades fraseológicas em textos traduzidos e adaptados do gênero noticia. Para ter uma ideia mais clara do papel dos idiomas e colocações no contexto do gênero notícias, recorremos aos materiais publicados

\footnotetext{
${ }^{1}$ Kazan Federal University (KPFU), Kazan - Russia. ORCID: https://orcid.org/0000-0002-5649-6995. E-mail: elvira-hadieva@yandex.ru

${ }^{2}$ Kazan Federal University (KPFU), Kazan - Russia. ORCID: https://orcid.org/0000-0002-3602-5686. E-mail: Khabibullinaelka@yandex.ru

${ }^{3}$ Kazan Federal University (KPFU), Kazan - Russia. ORCID: https://orcid.org/0000-0002-5094-3010. E-mail: Aralikberova2020@list.ru
} 
no período de janeiro a maio de 2020 em inglês, russo e turco nos principais sites de notícias. Ao mesmo tempo, selecionamos e analisamos artigos traduzidos e textos que são adaptações de informações da mensagem desejada. Além disso, foi dada atenção à questão da fraseologia das colocações. Pelo fato de ainda haver disputas quanto à distinção entre tradução (em decorrência da atuação do tradutor) e texto adaptado, foi necessário levantar a questão da definição de textos adaptados e traduzidos. Para criar um quadro completo, a pesquisa também incluiu a definição de outros termos e conceitos usados para se referir a um fenômeno linguístico em uma das três línguas dos textos acima. Nos textos de informação adaptados, existem numerosos exemplos de utilização de unidades fraseológicas, que em alguns casos coincidem em mensagens semelhantes em diferentes idiomas. Ao trabalhar com exemplos, seguimos as seguintes táticas. Para selecionar exemplos de textos adaptados, examinamos reportagens que continham as mesmas informações, tinham um link para a mesma fonte de informação e foram publicadas em um periodo de no máximo 24 horas. Também retiramos os textos de publicações homônimas publicadas em diferentes idiomas e destinadas a diferentes públicos potenciais, mas com as mesmas informações e publicadas com uma diferença de no máximo um dia. A adaptação mais comum de colocação deve-se à maior flexibilidade desses tipos de unidades fraseológicas.

PALAVRAS-CHAVE: Texto informativo. Língua turca. Língua inglesa. Colocação. Adaptação.

RESUMEN: El artículo aborda el problema de trabajar con algunas formas de unidades fraseológicas en textos traducidos y adaptados del género informativo. Para tener una idea más clara del papel de los modismos y las colocaciones en el contexto del género de noticias, recurrimos a los materiales publicados en el periodo de enero a mayo de 2020 en inglés, ruso y turco en los principales sitios de noticias. Al mismo tiempo, seleccionamos y analizamos tanto los artículos traducidos como los textos que son adaptaciones informativas del mensaje deseado. Además, se prestó atención a la cuestión de la fraseología de las colocaciones. Debido a que aún existen disputas sobre la distinción entre traducción (como resultado de la actuación del traductor) y texto adaptado, fue necesario plantear la cuestión de la definición de textos adaptados y traducidos. Para crear una imagen completa, la investigación también incluyó la definición de otros términos y conceptos utilizados para referirse a un fenómeno lingüístico en uno de los tres idiomas de los textos anteriores. En los textos informativos adaptados, existen numerosos ejemplos de uso de unidades fraseológicas, que en algunos casos coinciden en mensajes similares en diferentes idiomas. Cuando trabajamos con ejemplos, seguimos las siguientes tácticas. Para seleccionar ejemplos de texto adaptado, analizamos artículos de noticias que contienen la misma información, tienen un enlace a la misma fuente de información y se publicaron en un periodo no superior a 24 horas. También tomamos los textos de publicaciones homónimas editadas en diferentes idiomas y dirigidas a diferentes públicos potenciales, pero que llevan la misma información y se publican con una diferencia de no más de un día. La adaptación más común de la colocación se debe a la mayor flexibilidad de este tipo de unidades fraseológicas.

PALABRAS CLAVE: Texto informative. Idioma turco. Idioma inglés. Colocación. Adaptación. 


\section{Introduction}

In the adapted information texts, there are numerous examples of using phraseological units, which in some cases coincide in similar messages in different languages. The term «phraseological unit» (fr. unité phraséologique) was first introduced by the Swiss linguist Charles Bally, later the idea was more fully disclosed in the works of Vinogradov. The scientist identified four main types of phraseological units. These are:

- $\quad$ phraseological splices (idioms, semantically indivisible turns; value does not equal the sum of the values of the constituent elements);

- $\quad$ phraseological unity (the total value is derived from the sum of the values of the constituent elements, characteristic imagery);

- collocation (integral value is built from values of the constituent elements may limit synonymic replacement of components);

- $\quad$ idiomatic expressions (proverbs, sayings, clichés, aphorisms, catch phrases.

Modern scholars pay special attention to collocations in adapted texts in different languages. This is due to the next reason: the translation and adaptation of phraseological combinations with constant and variable elements gives the author or the person who adapts the text (let's call it a co-author or an adapter), some freedom of expression choice. Semantic flexibility, which is formed against the background of a variable element, increases the variation in usage.

\section{Results and discussion}

«Eastern cultures, in contrast to Western cultures, demonstrate a unique worldview» (MUHAMETZYANOV; GAJNULLINA; BOLOTOVA, 2020), which is revealed when comparing the components of the language process.

When working with examples, we followed the following tactics. To select examples of adapted text, we looked at news articles that contain the same information, have a link to the same source of information, and were published within a period of no more than 24 hours. We also took the texts of eponymous publications published in different languages and aimed at different potential audiences but carrying the same information and published with a difference of no more than a day. 
ABD Başkanı Donald Trump, ülkede koronavirüs nedeniyle can kayıplarının iki hafta içinde zirveye çıkabileceğini belirterek «Ölü sayısını 100 binle sınırlayabilirsek iyi bir iş yapmış olacă̆ıZ» dedi (BBC NEWS TÜRKÇE, 2020).

«The highest point of the death rate is likely to hit in two weeks,» Mr said(BBC NEWS, 2020).

In the context of a sentence the idiom «hit the high point» (culmination) is a constant element of collocation; the second element (rate is to hit) is a variable. In the Turkish text, the message is transmitted via the collocation «zirveye çıkamak», where the first element «zirve» (highest point, culmination) is a constant component, the verb «çıkamak» is a variable component of collocation. The integral value in both examples is preserved. The purpose of the statement is to report «beginning of the peak of death».

We have noticed that the translation of statements and quotations is the most accurate, almost verbatim. If a quotation contains any type of phraseology, then the adapter tries to preserve not only the meaning, but also all stylistic devices and expressive means. Note the following examples in reports in BBC World and BBC Russian.

«Olimpijskie igry «Tokio-2020» mogut stat' svetom v konce tonnelya», - dobavil Bah (BBC NEWS RUSSIA, 2020).

IOC president Thomas Bach: «These Olympic Games Tokyo 2020 can be a light at the end of this tunnel» (BBC NEWS, 2020).

IOC president Thomas Bach's speech is in both texts. The collocations «can be a light at the end of this tunnel» and «smogut stat' svetom v konce tonnelya» are comparable. The phrase «light at the end of the tunnel» is persistent and means «the end to something difficult or unpleasant» in both languages. Here, the adapter did a simple translation because the encoded value is recognized worldwide.

When working with adapted articles of the information genre in English, Turkish and Russian, we found that some publications when forming a lead (the first highlighted paragraph, abstract) to mitigate the negative message replace imperative forms of expression with phraseological euphemisms. Such expressions have the following characteristics: reproducibility, reinterpreted meaning, idiomaticality, structural and semantic stability and integrity (KOVALEVA, 2008). Some scientists believe that over time, a number of phraseological euphemisms lose a number of qualities and become idioms: the indirect nomination of an expression is not perceived as something camouflage, but reflects the national specifics of the language, its identity, and is a means of expressing the national picture of the 
world. In this regard, a number of «former euphemisms» are included in phraseological dictionaries (YILMAZ; TARASOVA; ASHRAPOVA, 2016).

For us, the issue of implementing collocations in translated and adapted texts in the cross-language context is relevant, using the example of Russian, English and Turkish. Special interest in the study of collections in the comparative aspect is caused by the fact that these collections, although present in all languages, differ in components that form a particular meaning. Collocations reflect the spectrum of traditional understanding of the word and represent the main feature of the language, acting as part of the traditional national culture, which «is the result of human wisdom that has gone through centuries of challenges and searches» (MUHAMETZYANOV; GAINULLINA; BOLOTOVA, 2019, p. 214). There are several definitions of collocation. We adhere to the definition proposed by Baranov and Dobrovolsky (2008): «these are weakly idiomatic phraseologisms mainly with the structure of a phrase, in which the semantically main component (base) is used in its direct meaning, and the compatibility with the auxiliary component (collocator) can be set in terms of a semantic class, but the choice of a specific word is predetermined by usus». Collocation consists of a free and non-free (key) component. The value of the first is completely preserved, its position is independent; the value of the second is determined by tradition, often in a figurative sense, it is dependent on the first component.

According to a number of scientists, collocation can be both phraseological and free. However, the collocation is not identical to the phraseology. Collocations are formed by rethinking the individual components of a combination. Collocation preserves the lexical meaning of one of its components, while the phrase itself is stable. The imagery of the key component weakens, which also affects the emotional load of the phrase itself. According to Vlavackaya (2011, p. 20), collocations occupy an intermediate position in the language system, being on the border between phraseology and lexicology. the Essential difference between collocations is that, unlike phraseological units, they do not have mutual influence of components.

Often collocations, as well as idioms, serve to replace taboo words. Here is an example from the text of the message about coronavirus published in English, Turkish and Russian, taken by us from news sites that link to a single source. The link to the source of information in all three articles is the same-the Spanish daily socio-political newspaper El Pais.

Spain has suffered its deadliest day so far in the fight against coronavirus with 950 people passing away in the last 24 hours (DAILYMAIL, 2020). 
İspanya'da, yeni tip corona virüs (Covid-19) salgınından dolayı hayatını kaybedenlerin sayısı son 24 saatte 950 artarak 10 bin 3'e yükselirken vaka sayısı 110 bini aştı (HÜRRIYET, 2020).

V Ispanii za sutki ot posledstvij zarazheniya koronavirusnoj infekciej COVID-19 skonchalis' 950 chelovek, obshchee chislo zhertv dostiglo 10003 (MUHAMETZYANOV; GAJNULLINA; BOLOTOVA, 2020).

The English text uses the idiom «passing away» (idiot to die) (MCGRAW-HILL, s/a). In the Russian version, the verb «скончаться» is used, which, according to Ozhegov, is a highsounding version of the word «umeret'» (OZHEGOV, 2015). The text in Turkish is based on the collocation «hayatı kaybetmek», where the constant component is the verb «kaybetmek». According to modern linguistic electronic dictionaries, this word initially has the meaning «die» in the semantic load: «yitirmek, yenik düşmek, yenilmek, mecaz anlamda ölüm dolayısıyla ayrılmak» (GÜNDELIK SÖZLÜK, s/a). Initially, the expressions «passing away» and «hayat1 kaybetmek» were euphemisms, but now the first expression is an idiom, and the second is a collocation

\section{Summary}

Quite often, the use of collocation is explained by the fact that the translation and adaptation of combinations with constant and variable elements gives the author/ co-author of the text some freedom of expression. Semantic flexibility, which is formed against the background of a variable element, increases the variation in usage.

\section{Conclusions}

Despite the fact that the twenty-first century is called the age of globalization, and according to the norms of international law countries are nominally equal, in every geostrategic region there are countries-leaders who set the tone (PARAMONOVA; MUHAMETZYANOV; EPSTEIN, 2018) In the process of analyzing the primary sources of information texts, we found that the leading countries not only set the tone for political and economic processes, but also dictate the attitude to what is happening in the world.

Thus, based on the research done, we can come to the following conclusions. First, the collocations of all three languages differ in their components and are often not directly translatable. Secondly, in order to prevent the use of coarse tracing paper, the authors of the 
adaptation text turn to free forms and collocations that are closest in meaning. in most translated texts, direct expressions are used. Third, the clearest work on translation and adaptation has been done in the quotes and statements given. Also, special attention was drawn to the fact that the elements of a collocation in some cases, there may be not only words but also phrases.

ACKNOWLEDGEMENTS: The work is performed according to the Russian Government Program of Competitive Growth of Kazan Federal University.

\section{REFERENCES}

BARANOV, A. N.; DOBROVOL'SKIJ, D. O. Aspekty teorii frazeologii. Moskva: Znak, 2008. $656 \mathrm{p}$.

BBC NEWS RUSSIA. Svet v konce tonnelya: Olimpiada $v$ Tokio nachnetsya $v$ iyule goda. 2020. Available: https://www.bbc.com/russian/news-52097761. Access: 20 Feb. 2020.

BBC NEWS TÜRKÇE. Koronavirüs - Trump: Ölü sayısını 100 binin altında tutmamız başar1 olur. 2020. Available: https://www.bbc.com/turkce/haberler-dunya-52089199. Access: 20 Feb. 2020.

BBC NEWS. Coronavirus: Trump extends US guidelines beyond Easter. 2020. Available: https://www.bbc.com/news/world-us-canada-52087113. Access: 20 Feb. 2020.

BBC NEWS. Tokyo Olympics and Paralympics: New dates confirmed for 2021. 2020. Available: https://www.bbc.com/sport/olympics/52091224. Access: 20 Feb. 2020.

DAILYMAIL. Spain coronavirus death toll hits 10,000 as a record 950 die. 2020. Available: https://www.dailymail.co.uk/news/article-8179745/Spain-suffers-day-recordcoronavirus-deaths-950-killed-24-hours.html. Access: 20 Feb. 2020.

GÜNDELIK SÖZLÜK. Available:

http://gundeliksozluk.speakdictionary.com/15873/kaybetmek/. Access: 20 Feb. 2020.

HÜRRIYET. Son dakika haberi: İspanya'da COVID-19'dan 950 kişi daha öldü. 2020. Available: https://www.hurriyet.com.tr/dunya/son-dakika-haberi-ispanyada-covid-19dan-950kisi-daha-oldu-41484623. Access: 20 Feb. 2020.

KOVALEVA, T. A. Frazeologicheskie evfemizmy v sovremennom anglijskom yazyke: dissertaciya ... kandidata filologicheskih nauk: 10.02.04. Kovaleva Tat'yana Anatol'evna. Kolomna, 2008. 160 p.

MCGRAW-HILL. Dictionary of American Idioms and Phrasal Verbs. Available: https://inosmi.ru/politic/. Access: 20 Feb. 2020. 
MUHAMETZYANOV, R. R.; GAINULLINA, L. A.; BOLOTOVA, N. A. The role of pavilion in aesthetics of korean garden-park complexes. Revista San Gregorio, v. 34, p. 214$219,2019$.

MUHAMETZYANOV, R. R.; GAJNULLINA, L. A.; BOLOTOVA, N. A. Edinstvo s prirodoj v korejskom sadovo-parkovom komplekse. In: Sovremennye vostokovedcheskie issledovaniya. 2020. p. 76-79.

OZHEGOV, I. S. Tolkovyj slovar' russkogo yazyka: 100000 slov, terminov i vyrazhenij. 28. ed. Moscow: Mir I obrazovanie, 2015. 1375 p.

PARAMONOVA, V.; MUHAMETZYANOV, R.; EPSTEIN, V. The issue of border demarcation between China and India in the second half of the XX century. Herald National Academy of Managerial Staff of Culture and Arts, v. 2, n. 2, p. 303-307, 2018.

VLAVACKAYA, M. V. Ponyatiya kollokacii i kolligacii v diahronicheskom rassmotrenii. In: Aktual'nye problemy filologii i metodiki prepodavaniya inostrannyh yazykov: mat-ly Mezhdunar. Novosibirsk: Izd-vo NGPU, 2011. p. 19-26.

VLAVACKAYA, M. V. Teoreticheskie osnovy kombinatornoj lingvistiki:

leksikologicheskij i leksikograficheskij aspekty: avtoref. dis. ... d-ra filol. nauk. Novosibirsk, 2013. $470 \mathrm{p}$.

YILMAZ, E. R.; TARASOVA, F. K.; ASHRAPOVA, A. K. Speech act of approval as a separate component of a positive assessment speech act. Journal of Language and Literature, v. 7, n. 2, p. 195-198, 2016.

\section{How to reference this article}

RAFILOVNA, Y. E; KAMILEVNA, K. E.; RAFISOVNA, A. A. Some phraseological units in the process of translation and adaption. Rev. EntreLínguas, Araraquara, v. 7, n. esp. 3, e021055, Sep. 2021. e-ISSN: 2447-3529. DOI: https://doi.org/10.29051/el.v7iesp.3.15722

Submitted: 10/01/2021

Required revisions: 20/03/2021

Approved: $23 / 06 / 2021$

Published: 01/08/2021 